\section{A NOTE ON THE OCCURRENCE OF LIPOPTENA CERVI ON A DEER IN WYANAD, KERALA AND ITS ZOONOTIC SIGNIFICANCE}

\author{
Roymon Jacob', Tincy Mary John¹, Reghu \\ Ravindran ${ }^{1,2}$, Bindu Lakshmanan ${ }^{1}$ and S. Rathish ${ }^{3}$ \\ ${ }^{1}$ College of Veterinary and Animal Sciences, Pookot, Wayanad, \\ Kerala 673 576, India \\ ${ }^{3}$ District Veterinary Centre, Kalpetta, Wayanad, Kerala, India \\ Email: ${ }^{2}$ drreghuravi@yahoo.com (corresponding author)
} web supplement

Hippoboscid flies belong to the family Hippoboscidae of the section Pupipara and are adapted for parasitic life. Most of them live on blood of mammals or birds. Among them, Hippobosca, Melophaga and Lipoptena are the main genera which parasitize mammals. The present communication reports the occurrence of Lipoptena cervi (Image $1^{\mathrm{w}}$ ) in a wild deer at Wyanad, Kerala and its zoonotic significance.

A Spotted Deer (Axis axis) was presented to the District Veterinary Centre, Kalpetta, Wyanad for postmortem after it had met with an accident. On external examination of the body, certain ectoparasites were seen clinging on the hair. They were collected in 10 percent formalin and brought to the Department of Parasitology, College of Veterinary and Animal Sciences, Pookot, for identification. The specimens were pale yellowishbrown in colour, and measured $0.5 \mathrm{~cm}$ in length and had no wings. They had soft leathery skin. There were three pairs of legs which were stout and the claws were strong. They were boiled in 10 percent Potassium hydroxide and dehydrated in ascending grades of alcohol. They were then cleared in creosote, mounted in Dibutylphthalate polystyrene xylol (DPX), and identified based on Sen and Fletcher (1962) and Bowman (1999).

The ectoparasite was identified as Lipoptena cervi, the louse fly of deer, based on morphological characteristics and the host from which it was recovered. These haematophagous flies are permanent parasites. The wings are fully developed on first emergence from the pupa but are shed as soon as they reach the host. The local people of Wyanad often complain about the attack of deer ked, which they colloquially refer to as 'deer tick', on humans. This could be due to the incidental bite of Lipoptena cervi, which is reported to cause skin lesions in man (Soulsby, 1982). In human beings the ectoparasite engorges on blood for 15-25 minutes. The bite is hardly noticeable and initially leaves a little trace. Within three days the site develops into a hard-reddened welt. The accompanying itch is intense and may last for 14-20 days; occasionally a pruritic papule may persist for even a year (Bequart, 1942). A complement cell mediated immune mechanism and IgE are involved in deer ked dermatitis (Rantenen et al., 1982). Since the etiological agent is unknown, it is presumed that the transmission of an infective agent, a bacterium or parasite through deer ked causes the disease. Dehio et al. (2004) could isolate Bartonella schoenbuchensis from the deer ked which was found to be colonizing in their mid gut. Halos et al. (2004) reported that Lipoptena cervi could play a role in transmission of Bartonella sp. in ruminants. The role of these infective organisms in causing dermatitis and transmission of them through $L$. cervi in Kerala needs to be investigated further.

\section{REFERENCES}

Bequart, J. (1942). A monograph of Melophaginae or ked flies of sheep, goat, deer and antelopes (Diptera: Hippoboscidae). Entomology America 22:1-220.

Bowman, D.D. (1999). Georgi's Parasitology for Veterinarians $\left(7^{\text {th }}\right.$ Ed). W.B. Saunders Company, Philadelphia, 16-17pp.

Dehio, C., U. Sauder and R. Heistand (2004). Isolation of Bartonella schoenbuchensis from Lipoptena cervi a blood sucking arthropod causing deer ked dermatitis. Journal of Clinical Microbiology 42: 5320-5323.

Halos, L., T. Jamal, R. Maillard, B. Girard, J. Guilliet, B. Chomel, M. Vayssier-Taussat and H. Boulouis (2004). Role of Hippoboscidae flies as potential vectors of Bartonella sp. infecting wild and domestic ruminants. Applied Environmental Microbiology 70: 6302-6305.

Rantanen, T., T. Reunala, P. Vuojolahti and W. Hackman (1982). Persistent papules from deer ked bites. Acta Dermatologica Venerologica 62: 307-311.

Sen, S.K and T.B. Fletcher. (1962). pp. 358-368. Entomology and Acarology in India. Indian Council of Agricultual Research.

Soulsby E.J.L. (1942). pp. 438-441. Helminths, Arthropods and Protozoa of Domesticated Animals. Bailliere and Tindall, London,

\section{ACKNOWLedGements}

The authors are thankful to the Associate Dean, College of Veterinary and Animal Sciences, Pookot, Wayanad for the facilities provided.

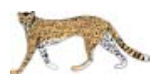

${ }^{\mathrm{w}}$ See Image 1 in the web supplement at www.zoosprint.org

(c) Zoo Outreach Organisation; www.zoosprint.org Manuscript 1439; Received 23 September 2005; Revised received 13 January 2006; Finally accepted 12 February 2006 ; Date of publication 21 March 2006 April 2006 | ISSN 0973-2535 (Print edition); 0973-2551 (Online edition) 